\title{
THE EMPOWERMENT OF KARANGPANDAN COMMUNITY THROUGH ECOLOGY-BASED LIVING BARN PLANT ARRANGEMENT SKILLS TRAINING FOR STRENGTHENING THE TOURISM
}

\author{
By \\ Sunarmi \\ Indonesian Art Institute of Surakarta (ISI), Indonesia \\ Email: sunarmi.intetior67@gmail.com
}

\begin{tabular}{l}
\hline Article Info \\
\hline Article History: \\
Received: $10-10-21$ \\
Revised : $13-11-21$ \\
Accepted: $28-11-2021$ \\
\\
Keywords: \\
Empowerment, Promotion, IT, \\
Arrangement, Education.
\end{tabular}

Arrangement, Education.

\begin{abstract}
Sawahan Karangpandan Village is one of the villages in Karangpandan, Karanganyar Regency, and it is a strategic village being a tourism village.Society has not entirely aware of the potential. Mostly, they earned their living by culinary business, planting living barn plants, decorative plants, and farming. It is strategic to be developed as a business during the Covid-19 pandemic. The PPM, the ISI Surakarta team, considers the importance of providing skilful education for the Sawahan Karangpandan community through the thematic Community Service Program in ISI Yogyakarta. The method employed is using Rapid Rural Appraisal (RRA) methodand Participatory Rural Appraisal (PRA) method. The result of Community Service shows that Rapid Rural Appraisal (RRA) method and Participatory Rural Appraisal (PRA) method can provide valuable skills to the community.Because the people in Sawahan village support training activities such as IT-based MSME's promotion strategy, decorative plants and living barn plantsbased competition, and education for the strategy to exist during the pandemic. The research result of training skills in arranging and promotion can be seen on Instagram with the following address https://instagram.com/kkn21_karangpandan?utm_medium=copy_link
\end{abstract}

Thisisan open accessarticleundertheCC BY-SAlicense.

CorrespondingAuthor:

Sunarmi,

Indonesian Art Institute of Surakarta

Email: sunarmi.intetior67@gmail.com

\section{INTRODUCTION}

In Sawahan Community in Neighborhood 06, Ward. 03, Karangpandan village, Karanganyar Regency, the contours of the land are hilly and located in the high lands in Karanganya Regency. The climate in Sawahan Hamlet has similarities with the other six tropical regions, namely the dry and rainy seasons. During the dry season, the sun feels scorching, and the temperature in Sawahan Hamlet can reach $33^{\circ} \mathrm{C}$, but the water supplywas still met. While in the rainy season, the plants become very fertile. The temperature in Sawahan Hamlet during the rainy season can reach $18^{\circ} \mathrm{C}$.

Sawahan community is one of the communities under the administration of Klathak Hamlet, Karangpandan Village, which most of the residents earned their living as farmers while having decorative plants and culinary businesses(Hamlet Head, SekDes, 2021). Like any other tourism village commonly observed in other places, the people in Hamlet take advantage by opening a culinary business. This business is their source of living. Meanwhile, for decorative plant business, the land used for planting is not specifically for plantation, but it only utilizes their little yard. As a result, the residents' cultivation of decorative and living barn plants has not been managed well to maximize as a business. The plants were sold to the people who come to the village or in the market(Hamlet Head, SekDes, 2021, Field Observation).

Based on the initial observation conducted by PPM ISI Surakarta, it is identified that the problem faced by the residents is the lack of knowledge about marketing systems both in plants and the culinary business. MSME (Micro-Small Medium Enterprises) could not exist yet as a business in the tourism village. The current temporary problems observed are the lack of publication in Karangpandan Village due to lack of concern or utilization of 
opportunities in Karangpandan as a tourism village. Lifestyle during the pandemic era has not been well understood by the residents(Aditiya Pratama, Agil (36)(Klathak Sawahan Head Village 2021, Interview on April).

\section{RESEARCH METHOD}

All this time, the Sawahan Karangpandan community's problems are that they have not understood the marketing strategy for their products and skills in managing their products. In the future, it is expected that all merchants will be aware of arranging their plants and able to innovate interior design in the culinary business. The merchants in Karangpandan need a good designer who could make them understand and provide skills in Interior Design to enhance their business more attractive. Therefore, it was proposed a solution the method of training and competition for the MSME's participant. The method createsa pattern involving people to make empowerment. Essentially, community empowerment aims to help the client gain resource, power, and the ability to conduct decisions and actions related to the client itself, including diminishing personal and social constraints(Payne 1997).The natural wealth of surrounding areas are the materials for interior elements design and IT progress, which is feasible to be empowered for effectiveness and efficiency. Ecological-based interior innovation is crucially instilled to the merchants to be a capital in continuing their business. Natural resources do not come from humans, but they couldimprove people's welfare (Menik 2018). Ecology focusing on recycling was expected to reduce expense or cost efficiency and establish a positive image regarding natural resources empowerment.

The empowerment methods applied are Rapid Rural Appraisal (RRA) method and Participatory Rural Appraisal (PRA) method. These methods explanations are as follows (Irawan, Wendi 2010):

\section{Rapid Rural Appraisal (RRA) Method}

TheRapid Rural Appraisal (RRA) method invites the community to learn and understand village potential. Based on the RRA method implementation, data collection was conducted through brainstorming between the facilitator and the merchants. In this phase, it was continued with problems analysis and problem-solving. This method was expected to recognize the merchants' own potential. The potential is crucial to be understood by the facilitator and the merchants themselves to build motivation to do creative innovation in interior design and promotional strategies.

2. $\quad$ Participatory Rural Appraisal (PRA) Method

TheParticipatory Rural Appraisal (PRA) method employs the approach stressing community involvement in an activity. In this method, the community is placed as research, planner, and executor of the program. The programingwas conducted by exploring Interior design and natural resources in the village. The facilitator invites the merchant to explore interior design in cyberspace and the surrounding environment with this method. Many examples could be learned of why interior design is essential in the culinary business. This method is expected could grow creativity over their potential so that it could be a capital to build creativity skills of interior design related to their business image. People were invited to formulate the concept and continued by implementing the strategy of interior design skills simulation. Within this method,the facilitator assigns the merchant participant to enrich motivation and awareness to implement creative designs to the business.

The outcome targets of community service in Sawahan Village, Karangpandang Regency are as follows: (1) fifteen (15) groups of merchants in Sawahan Karangpandan village learn the importance of interior design within a culinary business. (2) fifteen (15) groups of merchants in Sawahan Karangpandan village obtain interior design skills as their capital to expand their business. (3) fifteen (15) groups of merchants in Sawahan Karangpandan village have the skill to implement and make interior design innovation as their culinary business capital.

\section{RESULTS AND ANALYSIS}

The community empowerment activity in Sawahan Karangpandan village was conducted by a lecturer individually; in the practical implementation, the study involved 12 students. This way, involving students gives them experience in interaction and introducesthem to the community. The activity was conducted in several stages: preparation stage, socialization of the activity stage, execution of the planning stage, and evaluation stage.

The preparation stage was conducted before executing the PKM activity by all members and lecturers to discuss what material should be prepared. The discussion tries to describe the social condition to find the problems. Each of the members addresses their opinion after conducting their observation. In the Covid-19 pandemic, we implemented limitations, so it seems some of us did not detail in the observation. Therefore, each of the members delivers the information and complete each other.

Observation is a method to find out what is the situation and condition of the predetermined location. All PKM members conducted this activity in 20 days by the PPM team. This field observation is significant for arranging a working program. The observation result is the data or explanation obtained on the location's condition as the basis of planning the programs that agreed to coordinate with the village officers.

The program was formulated together with the team;accordingly, it was discussed with the village officers. The village officers were represented by Village Secretary and Village Head. The team choose an online presentation to deliver the program plan. Overall, the village officer has agreed to the program proposed by the 
PKM team. The village officials expected additional programs during the pandemic, considering Sawahan village has not received any socialization and education regarding Covid-19. Therefore, the program was set as follows(Integrated PKM team 2021, result of Joint Discussion). (a) MSME Strategy and Promotion. (b) Strategy to enhance Decorative plants MSME skills. (c) Education for the strategy to survive during the pandemic. Each of the programs was led by one of the PKM team participants. Each of the chairs in the event prepares the program by involving the residents and village officials. The sharing session activity for rehearsing the program was conducted intensely to correspond to the people's requirements.

The activity was conducted in the execution stage for 20 days, from 4 August 2021 until 24 August 2021, particularly in Neighborhood 06, Ward 03. The activity was arranged conforming to the theme, that is, Empowering Karangpandan Community Through Training of Arranging Living Barn Plants to Strengthening Tourism". In the first week of PKM activity, the team conduct Work Plan 1, e.g., MSME strategy and promotion, by making an online platform to promote all PKM activities in Karangpandan village. In the second week, the activity conducted was the team implementing work plan II, the strategy to enhance MSME decorative plant skills through competition. On the third week of PKM activity are the team executing work plan III, education in survival strategy during pandemic through distributing hand sanitizer and face-mask, and posting poster in Ward 03 Sawahan Hamlet. All activities were worked as planned. The village involvement in driving the community has a tremendous contribution to the program.

The pandemic situation was not an obstacle, and in fact, the activities were conducted online and offline. The training result of MSME promotion was conducted by accompanying and involving the community by the PKM team. Although Mobile Phone has become a daily life necessity, people are not accustomed to promoting their product online. So, we assist in promoting through Instagram, using people's mobile phones to promote their products. The address is as follows https://instagram.com/kkn21_karangpandan?utm_medium=copy_link

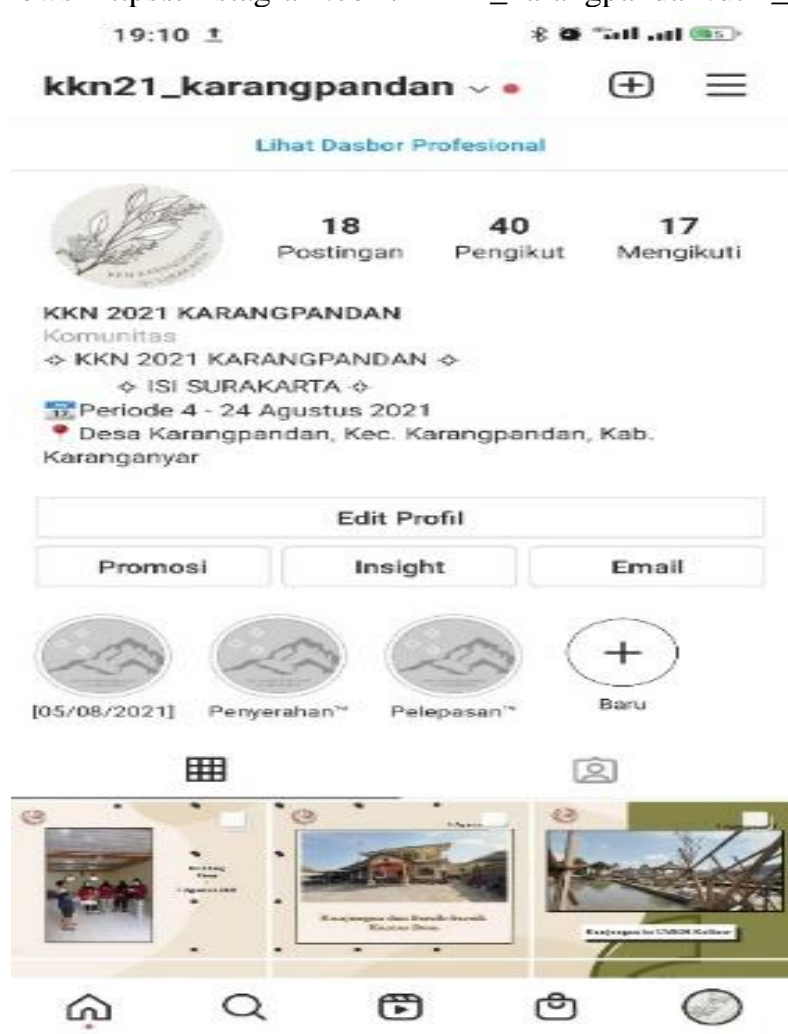

Figure 1. Training Result of IT-Based Promotion

The strategy provided reinforcement skills for the people in order the MSME had the skill to arrange their plant business, such strategy was conducted by providing training and making a competition. The skill of arranging plants and interior uses the strategy based on ecology. Utilizing natural resources to reinforce community, people will have art and design awareness. The materials surrounding the village were utilized as decorative or ornamental properties and interior design for culinary business. The people were enthusiastic in following the activity so that we could efficiently finish the material presented. People's involvement in the training was proven with the training result, that is, competition. The competition activities can be seen in Figure 2 as follows: 


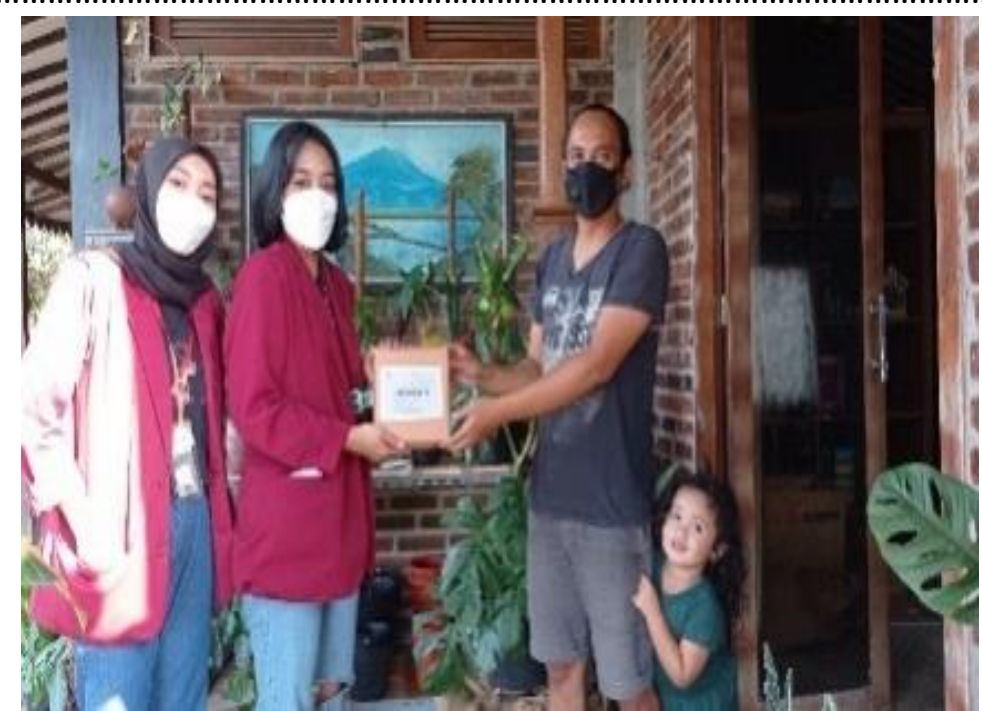

Figure 2. The award during Arranging Plant Competition

The strategy to reinforce the community to survive during the pandemic was held by conducting activities, such as socialization and publication health protocol. The lecture was followed by the people of Sawahan, then distributed hand sanitizer and posted brochures in public places and residents' houses. The activity in posting the health protocol brochure can be seen in figure 3 .

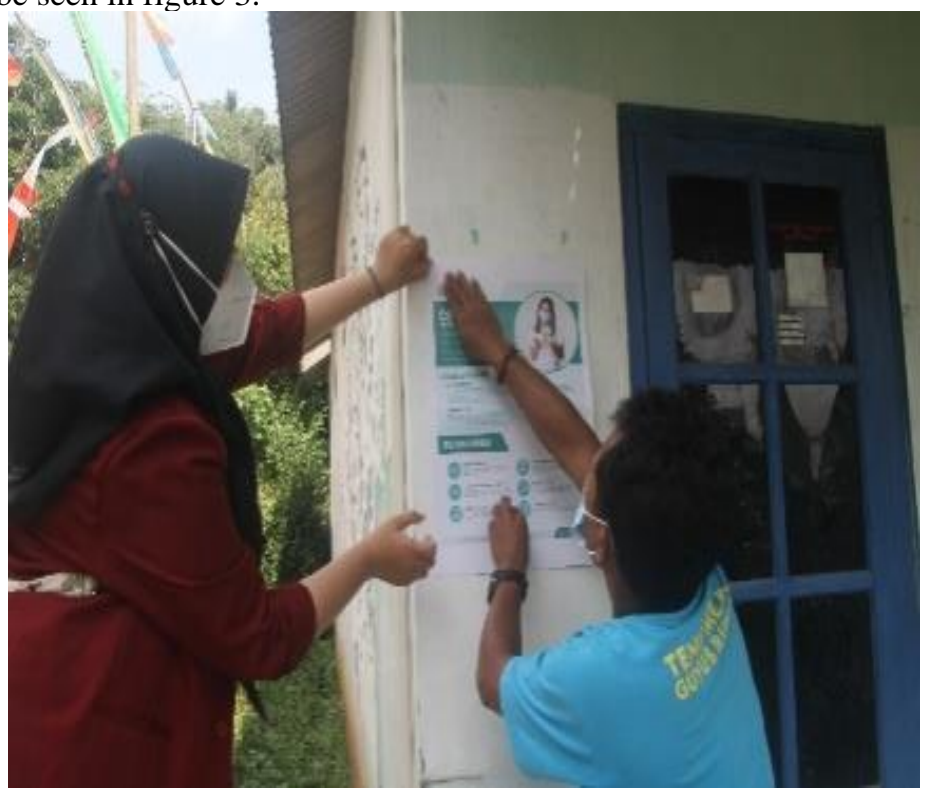

Figure 3. Posting Leaflet of Health Protocol in Pandemic Era

Evaluation stage, PKM activity in Karangpandan village, Karangpandan subdistrict, Karanganyar Regency, Central Java Province, was carried out for twenty days (20 days) from 4 August 2021 until 24 August 2021. The activity conducted during individual PKM was divided into three work programs, the description as follows:

Work Program I, MSME strategy and promotion through Digital Media. The activity aims to assist the residents in promoting products and businesses owned by the community through social media or digital media.The activity targetis ordinary people in Karangpandan Village. Rhei Nida Salsabilla led the activity. The participants have agreed with the method and material of promotion before executing the program. The assistance program conducted to twenty people is that 15 participants obtaineda good result. For the IT skills, instead of the parents, the youngster more understands these skills, it can be recognized in various similar events regarding community empowerment (Daniel Sului, Erric Soemarto, Nathaniel Alvin, Safiya Nada Arina, Stephanie Lai, Riyan Anggriawan 2020, 117-32). Therefore, this program was not only involving the elder's people but also the youth. The Mobile Phone condition and its operational ability need to be improved to get a satisfying result.

Work Program II, Strategy to improve Decorative plants MSME Skills. The activity aims to reinforce the people over their decorative plant business. The activity was conducted by holding a plant arrangement competition participated by the residents in Sawangan Hamlet. The Activity target is the ordinary people in Karangpandan 
Village. Aysa Kantun led the activity. The training was carried out in three stages; the overview stage on training resulted in interior design skill training in utilizing the surrounding natural resources presented by the PKM team. The next step is a simulation by the participant by proceeded with identification and gathering material of interior design as back up. Each participant wasexperimenting and assessing themselves and other participants. The awareness of the sense of art and design indeed affects the simulation result. Nevertheless, this little sense of art can be anticipated by continuous training so that people will improve their sense of art and design. Frequent appreciation and simulation training will improve the sense of art and design (Winarno Winarno, Hendro Aryanto 2016). Therefore, it is advised to the participant to train more often without being accompanied by the PKM team.

Work Program III is the strategy to survive in the pandemic era. The activity aims to provide reinforcement and strategy to survive during the Covid-19 pandemic. The activity was conducted by giving the preach and overview regarding the Covid-19 pandemic, continued by distributing face-mask, hand sanitizerand posting a poster educating on COVID-19. The activity target is ordinary people in Karangpandan Village. Retno Pantini led the activity. The information spread within the community regarding Covid is barely observed, making people careless about the danger of Covid. The lecture and presentation overview on Covid and its dangercan open people's minds to understand so that the activity can establish awareness within society. It must be understood that there is a significant relationship between awareness and consciousness, the understanding of Covid danger makes people always be aware of the pandemic (Amboro, Kian 2015, 109-17). It is better to be cautious than fall and infected due to carelessness. In this activity, it was observed that some people are careless with the situation regarding the pandemic. People who had been aware are involved in posting brochures about the strategy to survive during the pandemic.

\section{CONCLUSION}

The individual PKM activity in Sawahan Hamlet, Karangpandan Village, Karangpandan Subdistrict, Karanganyar Regency from 4 August 2021 until 24 august 2021 was conducted by employing a social and empowerment approach. The PKM team conducteda discussion with the village officials regarding the problems faced by the people. This stage was taken to determine the problems to find the answer as part of the PKM activity program. The method used employs field observation by cooperating with village officials and interviews. The literature study and methods of empowerment using training and competition. The empowerment method employed is Rapid Rural Appraisal (RRA) method and Participatory Rural Appraisal (PRA) method.

The success of PKM activity is because the village officials and resident give their tremendous support related to the information on the situation and condition so that this piece of information was helpful for the team to determine the answer for their problems. The village officials involvement, particularly the Village secretary and village head, was constructive for the team to arrange and execute the programs. All PKM participants under the lecturer's supervision were helped each other and kept on building cooperation, completing weaknesses and strengths to each other, strengthening cooperation, and providing their power, mind, and knowledge they have to the programs.So that it can build an independent student, respect each other, empathize with each other, and be responsible for the PKM program's success in Karangpandan village, Sawahan Hamlet.

The people in Karangpandan also supported the success in PKM activities, Sawahan village, they are enthusiast to welcome PKM team of ISI Surakarta. They are open to provide information regarding their problems in the village. MSME culinary and decorative plants still need specific skills to market their product in pandemic and industrial 4.0, in which almost all activities are IT-based. At the same time,the IT skills of the resident were still limited. In addition to the problems of arranging plants and interior design for their culinary business, most of them cannot present a sellable package in their design. The presence of the PKM team from interior design was expected can provide new ideas for MSME.

To strengthen the people during the Pandemic era, the activity was also directed to provide education during the Covid-19 pandemic. The PKM participant educates during the pandemic, andthey explain the danger and how to survive during the pandemic. The activity was also supported by distributing handsanitizer and face-mask, andthe socialization movement by posting posters to educate people about the Covid-19. This program was expected can provide education so that people are aware and cautious about applying 5M.

The activity was designed based on the agreement between the PKM team of ISI Surakarta with the village officials. However, pandemics remain to become the central issue in the transfer of knowledge. The limitation of proximity between the informant and the people in the training program and limitation in the meeting time, so people in Sawahan feel it was not enough to understand all the training lesson materials. Nevertheless, PKM programs have brought some results. Some people in the village can apply interior design skills, arrange decorative plants, and conduct marketing promotions through online media. This training result still has some weaknesses with the expectation of PKM team ISI Surakarta in Sawahan community, Karangpandan Subdistrict, and it would be solved. Some people still expect the PKM team's.presence provide more training for Sawahan people. 


\section{RECOMMENDATION}

The PKM activity online during the pandemic is very useful and expected by people. Nevertheless, it still needs to be improved in terms of the quality of training lesson material and the quantity of the team's presence in the community. Therefore, there are several recommendations for PKM teams and Sawahan village to maintain the activity to keep ongoing.

For the PKM team, it needs to add the time to prepare the concept or technical matters. The activity concept quality needs to be improved, particularly in promotion strategy. The training lesson material and method in promoting MSME culinary and decorative plants need to be enhanced its quality so that people can easily understand and practice it in their business. The IT training and interior design training need awareness in IT and art and design. The problem is the meeting in training is limited. Therefore, the quantity of training meetings needs to be added, and the intensity of meetings and training needs to be improved quantitatively.

For the Sawahan village, the commitment needs to be improved, particularly from the village officials to support driving the people to participate in community empowerment activities. The people who have participated in the training, the PKM team, are expected that they would apply and follow up the skills to their business and observe the impact of such training and pass the knowledge to their neighbours, so the process continues.

\section{REFERENCES}

[1] Aditiya Pratama, Agil (36) Head of Village Klathak Sawahan. 2021. "Socio-Cultural Conditions of the Sawahan Community."

[2] Amboro, Kian. 2015. "BUILDING AWARENESS BEGINS FROM UNDERSTANDING; THE RELATIONSHIP OF HISTORICAL UNDERSTANDING WITH HISTORY AWARENESS STUDENTS OF HISTORY EDUCATION STUDY PROGRAM FKIP METRO MUHAMMADIYAH UNIVERSITY.” Jurnal HISTORI 3 (3): 109-17.

[3] Daniel Sului, Erric Soemarto, Nathaniel Alvin, Safiya Nada Arina, Stephanie Lai, Riyan Anggriawan. 2020. "Pastries Business Empowerment And The Impact Of Renewal In Marketing, Operational, Human Resources And Financial Aspects." JPMI 2 (2): 117-32.

[4] Irawan, Wendi. 2010. Community Empowerment Method. https://www.scribd.com/doc/76408558.

[5] Hamlet Head, SekDes,. 2021. "Observing the Socio-Cultural Conditions of the Sawahan Karangpandan Community." PKM ISI Team Observation.

[6] Menik. 2018. "Manik, 2018. Pengelolaan Lingkungan Hidup. Djambatan: Jakarta Https://Www.Kompas.Com/Skola/Read/2021/04/16/163119269/Ekologi-Defenisi-Ruang-Lingkup-Asas-Dan Manfaatnya. Accessed in 2 June 2021 at 05.00.”

[7] Payne. 1997. "Definition of Community Empowerment." http://www.dosenpendidikan co.id/pemberdayaanmasyarakat. Accessed in 2 June 2021 at 05.30. http://www.dosenpendidikan co.id/pemberdayaan-masyarakat. Accessed in 2 June 2021 at 05.30.

[8] Integrated PKM team. 2021. "Discussion Between ISI PKM TEAM and Villages and Communities."

[9] Winarno Winarno, Hendro Aryanto. 2016. "EFFORTS TO INCREASE THE ARTISTIC SENSITIVITY ABILITY OF FINE ARTS EDUCATION UNESA STUDENTS FOR THE 2013 CLASS BY PAINTING USING WATERCOLOR AND WAX MEDIA." Dimensions of Art And Design 13 (1). https://www.trijurnal.lemlit.trisakti.ac.id/dimensi/article/view/1780/1540. 